\title{
Risk Mitigation of Covid-19 Pandemic in Baitul Maal Wat Tamwil
}

\author{
Esy Nur Aisyah ${ }^{1, *}$, Zuraidah Zuraidah $^{2}$, Ryan Rahmah Maulayati ${ }^{3}$ \\ ${ }^{1,2,3}$ Universitas Islam Negeri Maulana Malik Ibrahim Malang, Indonesia \\ ${ }^{*}$ Corresponding author. Email: esynuraisyah@pbs.uin-malang.ac.id
}

\begin{abstract}
Maintaining Baitul Maal Wat Tamwil (BMT) sustainability as an Islamic microfinance institution is very important because it can reduce poverty and increase economic growth. However, institutions usually face challenges, like the COVID-19 pandemic, which negatively impacts their sustainability. Therefore, the only way to keep such institutions functional and ensure financial progress is by practising risk management. Qualitative studies performed to analyze the lenitive effects of the risk management practices undertaken by BMT Maslahah Pasuruan and East Java due to the COVID-19 pandemic. Data collection conducted using interview techniques, documentation, and FDG (Forum Group Discussion). The results show that BMT has taken preventive steps in managing the risk. They optimized their marketing funding strategies to balance their outflows and members and cut down their cost, therefore overcoming financing inflow. Placement and distribution carried out selectively, using the suitable method and reserve losses on default debtors to avoid serious risks.
\end{abstract}

Keywords: Baitul Maal Wat Tamwil, Covid-19 Pandemic, Islamic Microfinance Institution, Risk Management.

\section{INTRODUCTION}

The Corona Virus Diseases (COVID-19) pandemic has caused many losses to economies worldwide, and it almost stops an economic activity. Based on the information reported in the daily Kompas.com that the spread of COVID-19 has an impact on economic activity and sharia business in Indonesia. There are several channels traversed by the effect of the COVID-19 outbreak in Indonesia. Rising risks in Islamic financial institutions are part of the track. Besides, the increasing risk has an impact not only on banking and non-bank institutions but also on Islamic microfinance institutions. Moreover, some Risks arise from this outbreak: financing, operational, market, and liquidity risks.

In this situation, risk management to minimize unexpected events. Financial institutions in which its operations are intermediaries are business activities that rely on third parties (depositors) to store their funds in financial institutions and then managed by channelling them in the form of financing to those who need them. Furthermore, risk management includes risk recognition, measurement, prevention, and supervision or control.

Based on the Ministerial regulation number 35.3/Per/ M.KUKM/X/2007, it reinforces to Islamic microfinance institutions that in facing liquidity risk, BMTs must overcome these risks by themselves in various ways be able to survive the threats they face. Therefore, BMT should set up a risk management model. Besides, risk mitigation is part of risk management in the form of concrete steps implemented by the institution dealing with all-risk conditions. It is on market risk, liquidity, operations, and financing.

The number of active cooperatives throughout East Java, both the regional scale and the regency/city scale, is 21,709 cooperatives (ODS data as of January 2020) and also the economic growth of East Java in the third quarter of 2019 macro-level has increased by $5.32 \%$ with a GRDP of Rp. 1,753.89 Trillion. When comparing the value with national economic growth of $5.02 \%$, East Java's economic growth is higher than the national economic growth. Shows optimism in economic development in East Java. One of the sharia cooperatives that has contributed to economic growth in East Java is BMT Maslahah.

BMT Maslahah Pasuruan is one of the fastdeveloping Baitul Maal Wat Tamwil in East Java. Twenty-one (21) years of work to build the country, BMT Maslahah contributed to enhance the capabilities and economic potential of the cooperative and the community, strengthen the economy of the people, develop the national economy, and enhance the creativity 
and soul of one organization for the youth of the nation. Based on the Management and Supervisory Responsibility Report Closed for the Fiscal Year 2019, the number of members (both registered members, savers members, financing members) increased by 23,250 people (6.98\%) 333,244 people in 2018 to 356,494 people in 2019. Then the office branches now number 101 with a total of 664 employees. Besides, the development of BMT assets should be accompanied by sound risk management to assess liquidity, smooth operation, the fulfilment of the collectibility of financing, and survive with existing market risks.

BMT took preventive steps to more attention to members to avoid liquidity risk [1]. Mitigate the risk of financing, members of sharia cooperatives were to mitigate starting from Input-Process-Output [2]. And the regulation and supervision had an impact on the implementation of risk management in Islamic microfinance institutions.

Wijaya found several ways to mitigate risk in the financing, namely a) collateral, b) risk transfer, c) late payment fines for able members d) allowance for receivable losses (PPAP) [3]. Based on previous studies' results, this study has several similarities related to mitigating some risks in Islamic financial institutions: financing, operational, and liquidity risk. However, in this research, another variable, namely market risk, has been included in a global phenomenon, the COVID-19 pandemic. Furthermore, the research results strengthened the research results that the COVID-19 pandemic had a significant effect on the worldwide economy in the short term [4].

Based on the results of interviews using online media with the Managing Director of BMT Maslahah Related to the condition of BMT during the COVID-19 pandemic, it sowed as follows:

"Until the end of March 2020, BMT can still increase revenue. In early April, the decreased member turnover due to the impact of COVID-19 has led to a decrease in credits payment. Consumptive factors withdraw savings. But, financial stability and liquidity remained under control."

Based on the explanation, this study aims to analyze the risk mitigation of the COVID-19 pandemic in BMT Maslahah Pasuruan, East Java.

\subsection{Risks of the COVID-19 Pandemic in the Financial Services Sector}

Based on BPS (Statistics Indonesia) data in the first quarter of 2020, Indonesia's economic growth declined in almost all sectors due to the COVID-19 pandemic impact. The spread of the COVID-19 virus also affects financial markets worldwide [5]. Therefore, the importance of early mitigation policies during pandemic shocks [6].

There were several risks in intermediary financial institutions [7]; credit, market, operational, liquidity, reputation, business, systemic, and moral hazard risks. From these risks, possible financial institutions can face more than one risk due to the COVID-19 pandemic. Yusgiantoro, as the Financial Services Sector Research Department at the Financial Services Authority, explained that the financial services sector's risks due to the COVID-19 pandemic were, firstly, liquidity risk to outflow third party, inflow credit, and outflow of funds. Secondly, reputation risk was a sentiment. Third, credit risk, namely the debtor's default [8].

\subsection{Risk Management in Sharia Microfinance Institutions}

When a business entity is was founded within sharia, by sharia economic objectives, wealth is distributed equitably among many hands without inflicting harm on them [9]. Legally can be done by allowing low-income earners to have easy access to microfinance institutions

The contribution of Islamic Microfinance Institutions in alleviating poverty with interest-free financing options and more flexible payment plans was the main factor. The redistribution of Islamic Microfinance Institutions over public donations to the poor in the form of Qard al Hasan (interest-free credit) also strengthened their role as essential contributors to poverty reduction [10]. Baitul Maal Wat Tamwil, as an Islamic microfinance institution with its financing products, can reduce poverty levels [11].

Risk is a common thing that must be faced by all financial institutions, and they cannot avoid it: however, they can take action to reduce it. Risk allows the outcome of an event that results in a detrimental situation. In the field of risk, finance refers to the loss of income and asset value. The term risk has various meanings in business and daily life. At the most general level, the threat utilizes to describe any situation where there is uncertainty about what will happen [12].

Based on the National Bank of Ethiopia (2010), it cannot avoid risk problems as an Islamic microfinance financial institution. An inherent element an integral part of financial services in general, microfinance in particular and indeed, some of the benefits are rewarded for risk-taking in business. On the other hand, excessive risk will cause harm, thus jeopardizing the safety of microfinance depositors. As a result, microfinance institutions may fail to meet their social and financial goals. So proactive risk management is critical to longterm sustainability. 


\section{METHODS}

The type of research used is descriptive qualitative; it analyzes an event faced by research subjects. For example, related to responses, behaviours, motivations, etc. were discussed thoroughly and then described using natural language and various scientific methods [13]. The object of this research is BMT Maslahah Pasuruan, East Java. In this study, the research subjects and informants were the Managing Director, Business Director, Head of Finance Division, Internal Controller Division, and the members of BMT Maslahah Pasuruan. There are three data collecting techniques. Those are interviews, documentation, and FGD (Forum Group Discussion).

\section{RESULTS AND DISCUSSION}

Based on the results of interviews with Managing Director of BMT Maslahah about the impact of the pandemic on BMT Maslahah's operations was as follows:

"This pandemic has an impact on BMT Maslahah operations. Besides, because of COVID-19, many members' savings will be withdrawn to meet needs during a pandemic. Members' credits also did not run smoothly because their business was affected by COVID-19 since this pandemic impacted the institution and a risk that BMT must face. Whereas, during the current month, BMT still survived despite the declining profits. Many BMT debtors can't understand the government message about the looseness of credit at the beginning of the pandemic. They assume that the regulation can cover all types of financing, but the looseness is only for the productive financing that is affected. And they do not pay credit because of misunderstanding".

Statement of the Managing Director of BMT Maslahah was also in line with the Head of the Finance Division's financial statements. Based on financial report in April 2020, the NPF Ratio increased by $2.6 \%$, and BMT's profits decreased by $9.3 \%$, and the savings balance in May 2020 decreased by 3\%. This figure showed a reasonably good performance amid a pandemic. Withstanding the various risks faced, BMT Maslahah had a variety of strategies as conveyed by the director of BMT Maslahah:

"When this pandemic happened, there were several steps that we had taken, namely several policies outlined in the form of instructions to all branches of BMT Maslahah, which numbered 101 in East Java. We at the centre continued to provide direction and motivation to our branch friends to continue to be creative and innovative in this pandemic situation; of course, there were different ways in each region. However, starting in May, this was predicted to be hard to survive because funding reduced/ more selective, which had a definite effect on the decline in income. But most important was enhancing communication and emotional connection between BMT with members to strengthen each other. That was, motivation remains optimistic and harmony in work and worship (increase Dhuha prayer, Qonaah, thankfulness, etc.) and encourage each other ".

The public communication strategy, especially for BMT members, is carried out effectively and massively in dealing with public sentiment over the COVID-19 pandemic. Furthermore, there are centralized policies that must be carried out by all branches of BMT Maslahah spread in East Java province. However, each region has a different way, several ways done by all BMT Maslahah. As stated by the Managing Director of BMT Maslahah and Business Director about liquidity risk mitigation, especially in the aspect outflow depositors:

"We can maintain a cash ratio of $30 \%$. However, many customers make withdrawals. COVID-19 pandemic did not have much impact on the withdrawal of savings in our BMT. The savings balance in May decreased compared to April by only $3 \%$, and even then due to withdrawals for the holiday's needs as per the annual cycle habits. At this, the position of idle money and do not have any bank financing dependents. We continue to make efforts and strategies to increase savings members by never delaying the withdrawal of savings continuously".

Furthermore, answers to research subjects about liquidity from the aspect of financing receivables (inflow of financing) were as follows:

"as I explained before, each region had its way, but friends had taken several steps to prevent the risk of this financing. Those were; 1) Educating and approaching customers regarding Covid-19 and cooperatives. Moreover, these cooperatives were not the same as banks or leasing under OJK. Education about financial management (such as a frugal lifestyle, spending priorities, etc.) and asset sales. 2) Providing a solution related to the decline in member income. 3) Relieving in principal installments. 4) Decreasing in the margin/Profit Sharing if the monthly margin of 1.5 is cut to 1,2 , etc., conditional. 5) Give souvenirs for credit membesr who pay smoothly. 6) Seducing a member by the employees".

Deteriorates cash flow of funds out in BMT Maslahah also be delivered as follows:

"In the current economic circumstances, to mitigate the risk, the money we save in the treasury, some savings in the bank. We are also a little worried if we save a lot of money at the bank. At the moment, banks have an unpleasant problem. Idle money/over liquid 
is also not good. Our principle is better to be overliquid than financing or investment expansion but at high risk. Besides, we temporarily revoked the application for funding except for those who truly believed in the prospect and repayment".

Related to BMT Maslahah profitability, research subjects explain as follows:

"Profitability is our homework. but thank God, the profit is still quite high, even compared to YOY 2019 as of May, is still higher now in 2020".

Regarding management financing risk during the pandemic, the Head of the Internal Control Division also explained as follows:

"There is a connection, internal control with financing. The realization of the funding, instalment payments that have the potential risk during a pandemic must be risk management, strategies, and others. The way that we have done is as follows: 1 ) Keep billing that is not affected, 2) Perform relaxation for those affected, 3) The ceiling for financing realization is limited. 4. Realization of financing only for businesses that are not affected directly".

To deal with the debtor's default, BMT reserves a loss financing loss fund. As stated by the research subjects:

"PPAP (Allowance for Earning Assets Losses in BMT has a PPAP policy of $15 \%$ (of the goal group. Less smoothly), 50\% (of the doubtful group), and $100 \%$ (of the bad goal). After deducting the collateral value, BMT also set aside 20\% (from SHU each year for reserve funds)".

Based on the above explanation, the risk mitigation of the impact of the covid-19 pandemic in BMT Maslahah is as follows:

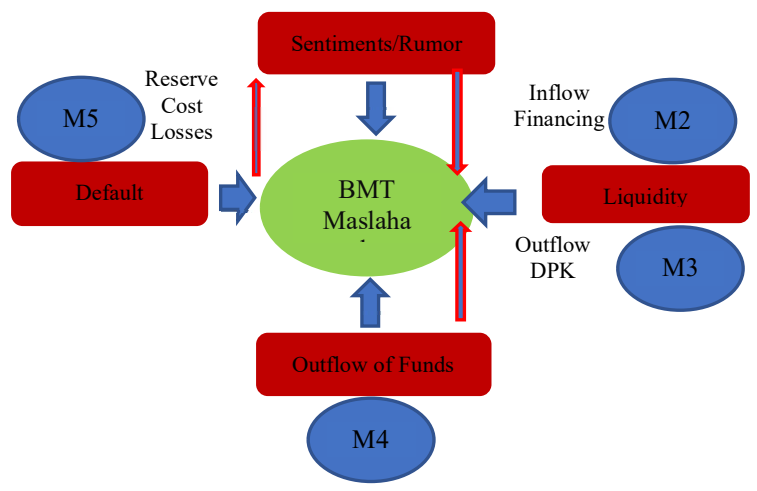

Figure 1. Risk Mitigation of Covid-19 Pandemic in BMT Maslahah

Based on Figure 1, there are five risks and mitigations in BMT Maslahah during the covid-19 pandemic. Those risks are rumors, liquidity, the outflow of funds, and default debtors. The Risk Mitigation of COVID-19 Pandemic in BMT Maslahah with several risk mitigations (M1, M2, M3, M4, M5). Creating sentiments in the community so that various rumours spread that could harm financial institutions. Therefore, mitigating emotions/rumours (M1), BMT effectively and massively conducts public communication, especially for cooperative members. Besides, the BMT uses Mass Media in facilitating community education.

The BMT established a policy of financial relaxation in mitigating liquidity risk over inflow financing. Relaxation of financing is to change the funding structure by the debtors' ability to pay credit during the pandemic. Delaying debt repayment and reassessing debt sustainability after conditions return to normal is one step that creditors must take to prevent debt crises during a pandemic [14]; [15].

The BMT implemented marketing funding strategies in mitigating outflows depositors. Marketing funding strategies can increase people's interest in saving and can be a competitive advantage for the company. Besides, the increase in inflow depositors through marketing funding strategies during the pandemic. Marketing funding Strategies can increase people's interest in saving [16] and can be a competitive advantage for a company [17]. Then the outflow of funds (M4) during the pandemic, BMT, is more selective in terms of placement/distribution of funds, especially in the realization of financing. The ceiling for financing realization is limited, and the financing realization is only for businesses that are not directly affected by the COVID-19 pandemic.

In the risk mitigation on debtor default (M5), BMT uses a cooperative strategy. The BMT still wants to have a long-term relationship in business with the customers. The The strategy was implemented by using restructuring efforts (such as rescheduling, rebuilding, and restructuring). Also, BMT reserves funds for loss financing losses in PPAP (Allowance for Earning Assets).

Under hibernation, due to the Covid-19 pandemic, a company must maintain good relations with workers, suppliers, customers, governments, and creditors. If all stakeholders share the burden of economic inactivity, companies are more likely to survive [18]. BMT Maslahah, as an Islamic microfinance institution, shares the responsibility of economic inactivity due to the pandemic. The government's cooperation to keep financial institutions survive with various financial risks during and after the Covid-19 pandemic.

The results of this study show that effective communication helps building trust and improving performance of a service industry, and the relaxation 
policy during the Covid-19 pandemic can reduce the risk of financial companies in liquidity and default debtors.

\section{CONCLUSION}

The Risk mitigation of the COVID-19 pandemic in BMT Maslahah Pasuruan, East Java, can be resolved with several mitigation measures. Optimizing strategies marketing funding to balance outflow of member funds and financing relaxation to overcome inflow funding. Placement and distribution of funds more selectively to avoid very high risks. Besides, use a cooperative strategy and reserve losses on the debtor's default.

Research related to risk mitigation can be discussed more particularly during the Covid-19 pandemic, as many financial institutions are affected by the pandemic. A significant limitation of this study is the study sample; since the example covers only one regency in East Java province, Indonesia, it does not represent the whole of East Java or Indonesia. Researchers can further add other districts and other areas to look at the mitigation risks experienced by Islamic microfinance institutions in Indonesia during the Covid-19 pandemic. The broader scope could be by researching one of the OIC countries that have Islamic microfinance institutions. This research is an empirical study that discusses risk mitigation in Islamic microfinance institutions so that this research makes a unique contribution to Islamic financial literature.

\section{AUTHORS' CONTRIBUTIONS}

This research has a contribution for the current conditions, where the concept of this study follows the current state of conducting research related to mitigation risk in BMT during the Covid-19 pandemic period. Data collection showed using interview techniques, documentation, and FDG (Forum Group Discussion) so that the collected data is more accurate. Data analysis carefully, so that accurate results are obtainable. The standard preparation prepares articles for research articles. Researchers will make revisions and will follow the final decision before the item is published.

\section{ACKNOWLEDGMENTS}

BMT Maslahah Pasuruan, East Java, supports this research. We thank to BMT Maslahah's colleagues, who have been willing to provide data and information related to this research to be completed in time.

\section{REFERENCES}

[1] S. A. Susilo and D. F. Septiarini, "Manajemen Risiko Likuiditas di BMT ABC Jawa Timur,"
Jurnal Ekonomi Syariah Teori dan Terapan, vol. 2, no. 6. pp. 1-15, 2015. DOI: http://dx.doi.org/10.20473/vol2iss20156pp\%25p.

[2] Z. A. Firdaus, "Mitigasi Risiko Pembiayaan di Lembaga Keuangan Mikro Islam," Doctoral Dissertation. Universitas Airlangga, 2014, [Online]. Available: http://repository.unair.ac.id/39506/.

[3] R. Wijaya, "Analisis implementasi mitigasi risiko pada pembiayaan murabahah di KSU UJKS Jabal Rahmah Pulosari Waru Sidarjo," Doctoral Dissertation. UIN Sunan Ampel Surabaya, 2018, [Online]. Available: http://digilib.uinsby.ac.id/26190/.

[4] N. M. Ferguson et al., "The Global Impact of COVID-19 and Strategies for Mitigation and Suppression," Imp. Coll. COVID-19 Response Team, 2020.

[5] D. Zhang, M. Hu, and Q. Ji, "Financial markets under the global pandemic of COVID-19," Financ. Res. Lett., 2020. DOI: 10.1016/j.frl.2020.101528.

[6] F. Kimura, S. M. Thangavelu, D. Narjoko, and C. Findlay, "Pandemic (COVID-19) Policy, Regional Cooperation and the Emerging Global Production Network†," Asian Econ. J., 2020, DOI: 10.1111/asej.12198.

[7] E. Susilo, Analisis Pembiayaan dan Risiko Perbankan Syariah. Yogyakarta: Pustaka Pelajar, 2017.

[8] Yusgiantoro, "Covid-19 dan Bisnis Syariah." kompas.com, 2020, [Online]. Available: https://money.kompas.com/read/2020/04/01/19200 0226/covid-19-dan-bisnis- syariah.

[9] Muhammad Al-Tahir Ibn Ashour, Ibn Ashur: Treatise on Maqasid al-Shariah. 2006.

[10] J. Effendi, "The role of Islamic microfinance in poverty alleviation and environmental awareness in Pasuruan, East Java, Indonesia." 2017. DOI: https://doi.org/10.17875/gup2013-230.

[11] N. I. Riwajanti, "Islamic Microfinance in Indonesia: A Comparative Analysis between Islamic Financial Cooperative (BMT) and Shari'ah Rural Bank (BPRS) on Experiences, Challenges, Prospects, and Roles in Developing Microenterprises," Bull. Indones. Econ. Stud., 2014. DOI: 10.1080/00074918.2014.980385.

[12] S. O. Saldana-Zorrilla, "Assessment of disaster risk management in Mexico," Disaster Prev. Manag., 2015, DOI: 10.1108/DPM-11-2013-0201.

[13] A. Bandur, No Title. Jakarta: Mitra Wacana Media, 2016. 
[14] Tientip Subhnij and Zenathan Hasannudin, "Financing SDGs under a new normal: Challenges and response to COVID-19 pandemic | United Nations ESCAP," UN ESCAP, 2020.

[15] V. Welch, "Evidence from Campbell systematic reviews on the economic response to Covid-19," Campbell Collaboration, 2020.

[16] Ismawati, "Peran dan Strategi Marketing Funding Dalam Meningkatkan Minat Nasabah Pada Bank Syariah Mandiri KCP Panakukang Kota Makassar," Al-Mashrafiyah J. Ekon. Keuangan, dan Perbank.
Syariah, vol. 3, no. 1, pp. 70-82, 2019. DOI : https://doi.org/10.24252/al-mashrafiyah.v3i1.7740.

[17] Akhmad Fauzan, "Strategi Syariah Marketing Funding Products Koperasi Jasa Keuangan Syariah dalam Meningkatkan Keunggulan Kompetitif: Study Kasus di KJKS PP. Matholi'ul Anwar Kabupaten Lamongan," Doctoral Dissertation. UIN Sunan Ampel Surabaya, 2016, [Online]. Available: http://digilib.uinsby.ac.id/6473/.

[18] T. Didier, F. Huneeus, M. Larrain, and S. L. Schmukler, Financing Firms in Hibernation During the COVID-19 Pandemic. World Bank, 2020. 